\title{
Methodological Innovations, Reflections and Dilemmas: the hidden Sides of Research with Migrant Young People Classified as
}

\section{Unaccompanied Minors}

Elaine Chase and Laura Otto, in collaboration with Milena Belloni, Annika Lems and Ulrika Wernesjö

Abstract (150 words)

This paper offers some behind-the-scenes insights drawn from the collective fieldwork experiences of the contributors to this Special Issue. These include reflections on: how decisions about modes of accessing research participants fundamentally shape the research process and outcomes; the pitfalls of only focusing on young people's migratory experiences while ignoring the multiple other dimensions to their lives; how we can best capture and represent young people's often paradoxical vulnerability and agency; the relative merits of methodological innovations increasingly integrated into work with marginalised and hard to reach communities; and, finally, our own positionality when conducting research with migrant young people and the importance of taking account of how our own subjective, political, philosophical and ethical standpoints influence our interactions throughout our research endeavours. These contributions seek to promote greater reflexivity and transparency among academics conducting ethnographically driven research with young people in the context of forced migration.

Key Words: young people, forced migration, research ethics, ethnographic methods, positionality 


\section{Introduction}

When we met as a team to discuss our contributions to this volume, we spoke at length about how little is written about the hidden face of the research process and the sorts of daily dilemmas we encounter as anthropologists and sociologists in different contexts. While some previous contributors have considered the peculiarities of research with young refugees (Vervliet et al. 2015; Rousseau 1993), central issues such as the complexities sustaining young people's participation and the development and use of creative methods have not been sufficiently discussed. Moreover, we saw this as an opportunity to reflect on the various pitfalls and challenges we had encountered through our research to raise awareness among others working in the expanding field of child and youth migration. We were also aware of our roles as contributors to the ways in which the 'refugee' child or young person is framed, presented and analysed in public, political and policy discourses (Lems, Oester and Strasser, this issue).

Conducting research with unaccompanied migrant young people, despite certain similarities of research with adults (Punch 2002), presents a unique set of conundrums and contradictions which we felt merited some collective reflection and deconstruction. This paper offers insights drawn from the fieldwork experiences of the special issue contributors around five core themes which we rarely have space to consider but which may fundamentally influence both the research process and the conclusions we draw from our work. We start with the dilemmas concerning how we negotiate access to research participants, recognising the inherent biases in, for example, accessing them through statutory services, through purposefully approaching them only through non-governmental or civil society organisations, or alternatively through family and social networks. In each case there are risks of selection bias, of silencing particular voices and of spotlighting certain experiences while ignoring others. We then discuss a key issue relating to the dangers of over-essentialising young people's migratory experiences while overlooking the multiple other facets to their lives. 
Central to this issue is not only the language and terminology we employ in representing young people who experience (forced) migration and who we write about in our research, but also the aspects of their lives that we focus and the risks of reproducing tropes and stereotypes embedded within the bureaucratic labels used to categorise these young people. A third dilemma relates to how we reconcile the inherent vulnerabilities and frailties generated by young people's circumstances with their resourcefulness and agency to navigate and respond to the adversities they face. A fourth theme considers the types of methodological innovation increasingly integrated into work with marginalised and hard to reach communities, in particular, the use of arts-based methods and peerled approaches to research. We discuss not only the advantages of working in these ways but also critically reflect on some of the new dilemmas that adopting such approaches throw up for researchers and research participants alike. A final set of reflections relates to our own positionality when conducting work with young people who face potential marginalisation and discrimination and the ways in which we must constantly straddle our own political, philosophical and ethical standpoints with maintaining investigative rigour for the purposes of social science research. Moreover, we reflect on two important sets of power dynamics emerging through our research: the first relates to the fact that the majority of contributors to this volume were established White ${ }^{1}$ European researchers conducting research with young people from the Global South; the second considers the effects of an all-female team of researchers working predominantly with male participants. Although these themes are introduced separately in different sections of the paper, inevitably there is intersection between them. The following contributions seek to promote enhanced reflexivity in our work, encourage transparency and openness about the fissures and flaws in research and to offer insights into what we have learnt in the pursuit of improved ethnographically driven research with young people.

\footnotetext{
${ }^{1}$ In line with Critical Whiteness Studies, we understand White and Whiteness as socially constructed and not as biological facts.
} 


\section{Negotiating Access}

At the design phase of any project, one of the first questions researchers face is how they intend to identify participants and then invite them to take part in a study. A number of ethical and practical issues emerged from our experiences with respect to how access is negotiated and managed in the context of research with refugee youth. Wernesjö's work in this volume investigated the experiences of migration and of establishing a life in Sweden for unaccompanied young refugees with permanent residency (Wernesjö, this issue). A major challenge in this work was the lengthy and time-consuming process of negotiating access to young people categorised as underage through gatekeepers. Her research was conducted prior to the establishment of two non-governmental organisations which now organise care for unaccompanied young people (Ensamkommandes förbund and Sveriges ensamkommandes förening). This meant that contact with refugee young people had to be established through statutory municipal social services departments and residential care units, reflecting the institutionalised nature of the reception and care arrangements for unaccompanied minors in Sweden (Wernesjö 2014). While working through formal care structures has practical drawbacks - it took for example more than six months from initially approaching these services to when the research actually began - there are other more fundamental constraints to working in this way. Hopkins (2008), amongst others, has highlighted how unequal power relations may mean that young people fear that declining to participate may negatively impact their relationships with those in positions of authority and may have consequences for their life situation in general (Hopkins 2008; Fernqvist 2013). Moreover, in situations where research findings may reflect on the quality and or impact of practice and policy, in social care or education for example, there may emerge certain biases with respect to determining which young people get onto the potential participants' list. For example, gatekeepers' understandings of the 'best interests' of children and young people can largely determine not only researchers' access to the research 'space' but also which young people are able to occupy it. On the other hand, access via statutory 
gatekeepers, such as social workers or teachers, may have advantages since they can provide a buffer between researchers and research participants, benefitting researchers through advising how to best approach and establish contact with young people, while at the same time ensuring that young people have an opportunity to discuss the nature of their participation with someone who has no vested interest in the research itself (Wernesjö 2014, 58). Convincing gatekeepers - including foster carers and guardians who take on the role of parents - of the potential value of research is a vital part of negotiating access to research participants. It requires spending time to build relationships and find creative ways, which may not be immediately obvious, of working together with others. This essential time is rarely strategically allocated in the research process.

In her work described in this special issue, Wernesjö's strategy was to identify young people for the research through statutory gatekeepers and to then purposefully distance herself from the gatekeepers. This meant that Wernesjö could reassure young people that no further contact or sharing of information between researcher and gatekeepers would take place. Given how young people in previous research have described how they are selective in what they share with statutory gatekeepers (Chase 2010), such reassurances may be helpful in giving young people greater freedom to speak openly about their experiences.

When preparing her entry into the field, Lems (this issue) encountered a major obstacle in convincing the organisation responsible for the care of unaccompanied minors to permit access because of their concerns about their perceived vulnerability (Goździak 2008). While notions of empowering children and young people through listening to their voices have become central to many research projects, social care professionals, as Lems discovered, may be wary about such approaches. Staff she encountered were particularly concerned that having an ethnographer present would disrupt the daily routine in the facility or pressure the young people into revealing details about their lives that could be used against them. However, working directly with a member who 
had recently initiated a radio project with young people living in the facility, Lems was able to develop a way of conducting participant observation in the residential care space that felt more "participatory" and less like "observation". Through the radio project, it became possible to work collaboratively with young people to frame the stories they wanted to tell and which were then aired on an independent youth radio station.

In the broader context of research with unaccompanied migrant young people, working only through formal systems and structures automatically excludes those young people who are no longer eligible for statutory services or who may have purposefully disengaged for fear that maintaining contact might jeopardise their ability to remain in the host country. In their work with unaccompanied migrant young people turning 18, Chase and colleagues (Chase and Meloni, both this issue) purposefully sought access to potential research participants only through non-statutory services and through migrant young people's wider social networks. This process was facilitated by having a core team of young researchers all of whom had previously migrated as unaccompanied children to the UK. Working through non-statutory and informal networks made it possible to include young people facing very diverse outcomes and circumstances as they turned 18 . Through these less formal networks young people working as research assistants were more easily able to build trust and practically enable young people to participate irrespective of their legal status, living arrangements or command of English. Yet while the access box was successfully ticked in this way, the approach also had other, sometimes problematic consequences for the research assistants and arguably generated a new set of power dynamics in the research process (Haile et al. 2019), a point we return to later in the section on positionality.

Similarly, Belloni (this issue) describes how, through her multi-sited research in Eritrea, Ethiopia and Sudan, she sidestepped statutory and institutional actors and, instead, worked through existing friendship, family and social networks. This, she found, shifted her own observed positionality from 
researcher to guest, friend or lonely foreigner, depending on how she was introduced to potential participants and enabled her to build rapport in contexts of sometimes extreme mistrust and vulnerability (Daniel and Knudsen 1995). Through embedding herself in a transnational family network, Belloni came to better understand the complexities surrounding decisions to embark on life threatening journeys and how these were shaped by both families' and young migrants' perceptions, fears and hopes about their futures (see also Belloni 2016b).

Across the different research projects in this volume, and as captured through previous research (see also Wahlström Smith and Ascher 2016) migrant young people occupied a broad range of relative positions of marginalisation and opportunity. As researchers, how we negotiate and navigate access to participants fundamentally shapes the extent to which we can articulate the nuances and complexities of migrant young people's lived experiences for the purposes of enriching theory, policy and/or practice. Finding ways to avoid biases in access in the first place; critically interrogating the trade-offs in the decisions we make about negotiating access; moving from a purely harm minimisation approach towards research that may have mutual benefits (Mackenzie et al. 2007); and being transparent about the rationale for decisions surrounding access and their subsequent consequences in our reporting, are practices which we feel should become embedded in future research endeavours.

\section{Over-essentialising the Migrant Experience}

All research, whether we are conscious of it or not, is shaped by certain a priori ascriptions, assumptions and expectations (Reichertz 2015). These range from what is already known about the research participants we are focusing on, how we hope they will cooperate, and the things we expect them to tell us. 
To begin with, state, intra-state and bureaucratic procedures tend to categorise unaccompanied children and young people in the context of (forced) migration in particular ways. The 'asylum seeking'; the 'unaccompanied'; the 'separated' child - or commonly the institutional code 'UASC' (unaccompanied asylum-seeking child) or 'UAM (unaccompanied minor) are all used to distinguish such children from others within social care, health and education systems and to differentiate them in immigration statistics. Such processes tend to assume that young people classified in the same way automatically have a shared experience. Without careful reflection as researchers, we run the risk of reproducing these categorisations and making assumptions about what young people have been through and how this has impacted their lives. Moreover, these existing categories exclude young people in situations of (forced) migration who are not marked and classified in institutional terms. Thus, how young people are labelled, what kind of behaviour is considered 'normal' within a particular category, to what extent - if at all - they are placed in institutionalised settings, and whether the (geographical and legal) contexts they find themselves in consider them 'children' or 'underage', are all time and space contingent and remain relational categories (Spyrou 2017; see also Otto this issue). As researchers, we need to be mindful of the terms we use to write about young people and their experiences, crucially positioning ourselves within these wider discursive frames and making it clear why we decide to apply certain terms or labels to their situations, or why we refrain from their usage. Throughout this volume we refer broadly to young people who have experienced forced migration in a multitude of different ways and suggest that while there may be similarities in how different young people have lived through forced migration, there are likely to be as many differences. Moreover, as illustrated by Belloni's work with young people in Ethiopia and Sudan (this issue), participants may actively resist the bureaucratic categorisations imposed on them so as not to be trapped within the humanitarian system. 
Perhaps linked to the idea of resisting being labelled in particular ways, young people commonly also resist the dominant 'horror' tropes associated with their migration. Our expectations of what to hear are often linked to our own "interpellation" (Althusser 1972) of young people as 'unaccompanied minors'. It is easy then to inadvertently ignore young people's own subjectification and self-making processes beyond the powerful labels they are tagged with. In listening to young people's accounts, the process of migration is only one aspect of their young lives which are simultaneously shaped by many other opportunities, struggles, identity conflicts and interests. Ethnographic approaches to research allow for more open and rounded narratives to be told by young people which recognise the multiple aspects to their lives and recognise them as important social actors (e.g. James 2007; Franks 2011).

Furthermore, ethnographic and sociological modes of enquiry can counter purely quantitative approaches which are often based on prior assumptions and prone to essentialise young people's refugee experiences (Wernesjö 2012; Malkki 1995). More open, exploratory methods enabled researchers writing in this issue to capture processes of subjectification within and beyond given categories and assumptions about young people who have experienced displacement (Otto and Kaufmann 2018). Given the opportunity, there are many other stories that young people want to tell beyond their migration and what happened en route. It is important to also realise that young people are not immune to the expectations surrounding the stories they should tell. Otto (this issue) discovered that the young people she worked with tended to first present the same developed narratives they told Maltese authorities about themselves and about their reasons to flee their country of origin. It took several weeks of Otto's presence in the state care facility where the young refugees were housed, before they approached her and communicated a desire of telling their stories in a different way. Lems (this issue) also found that it took time before young people stopped recounting officially acknowledged stories, but started to open up a bit more. Intimacy and time are thus key in creating spaces which allow young people to construct and present more complex 
representations of themselves. Once given this space through the radio project, Lems' found that research participants, rather than talking about their refugee experiences, concentrated on creating a picture of themselves as 'normal' and 'ordinary' teenagers - narratives which also helped to illuminate their struggles in Switzerland. Similarly Chase and colleagues' work with unaccompanied migrant young people becoming adult in the UK found that young people wanted to talk about many other aspects of their lives including their own search for intimate relationships, their future goals and their aspirations for marriage and family life (Chase and Allsopp forthcoming; Allsopp 2017)

There is no doubt that more research is needed to better understand the processes and impact of classifying and categorising young refugees in particular ways and the struggles associated with their migratory status. However, an important question for researchers is how best to avoid focusing so much on the experience of forced migration to the point that we ignore other important aspects of young people's lives. We found it helpful to adopt a relational approach which focuses on how young people work through multiple other life transitions simultaneously with their experiences of migration.

\section{Agency and Vulnerability}

All the authors who contributed to this special issue frequently have come across young people who differed from the conventional idea of the 'unaccompanied minor', that is someone widely assumed to epitomise vulnerability. On the contrary, many young people purposefully sought to create a selfimage of being capable, of being strong, and of acting responsibly. Yet we find that asylum, immigration and social care systems attribute a certain 'inscribed vulnerability' to unaccompanied young people and this brings with it a number of problems. This reflects the observation by Fineman $(2008,8)$ that "[T]he concept of vulnerability is sometimes used to define groups of 
fledging or stigmatized subjects, designated as 'populations", adhering to a certain 'groupism' (Goel 2015)

As a result, unaccompanied young people are placed in a position in which they have to manifest a certain type of 'vulnerability' in order to be deemed eligible for the support they require as members of a vulnerable group. Moreover, this inscribed 'vulnerability' ignores the fact that such vulnerability is, as Butler (2009) would define it, politically-induced. The authors of this special issue do not equate the agentive behaviour we observed as an expression of young refugees being invulnerable, but rather suggest that agency and vulnerability must not be understood as mutually exclusive. The debate on young refugees as either being 'vulnerable victims' who flee in despair and thus 'deserve refuge' on the one hand, or as 'asylum system abusers' who seek a better life and are viewed as 'bogus refugees' on the other hand (Holmes and Castaneda 2016) puts researchers in a certain dilemma: How can we write about their agency without fostering views of young refugees as 'asylum system abusers'? And how can we prevent young refugees from being denied support based on our research findings?

Belloni (this issue) has considered the difficulties of representing young refugees as active social agents without neglecting that they sometimes also need support. Addressing this dilemma requires a relational understanding of agency and vulnerability which recognises how structural violence, power imbalances and legal borders all need to be considered as limitations to the freedoms which young refugees encounter. Belloni addresses the 'appropriateness' of the question of writing about young refugees' agency by comparing their behaviour to that of other youths who did not experience forced migration. Hence, conceptualising young people's migration across different global contexts within a wider frame of human mobility, moves away from ideas of migration as being exceptional and rather captures it as a normal part of life and a demonstration of individuals' 
capabilities to take a degree of control over their lives (see also Carling 2002; Lubkemann 2008; Belloni 2016a, 2016b).

As captured throughout the work in this special issue, migrant young people are subjected to a myriad of institutional processes. Understanding when, how and why young people are vulnerable and/or act in agentic ways is contingent on understanding these institutional processes and how agency might emerge in response to them (Fineman 2008; Chase this issue). Moreover, we need to be aware of how the label of vulnerability repeatedly assigned to unaccompanied migrant young people defines them as perpetual victims and as 'the other', rather than recognising that vulnerability and frailty are intrinsic to the human condition (Fineman 2008; Chase 2018). A further important reflection relates to how we as researchers may become active in processes of vulnerabilisation, as well as in promoting young refugees' agency through, for example, forwarding important NGO contacts to enhance support networks or discussing possibilities of family reunification with them. It is thus sometimes the case that we intervene and enable young refugees to act in more agentic manners, before we then write about their agency which we might have (partly) facilitated in the first place. As a result, agency - its conditions and its acting-out - must be understood as a co-constructed process, in which social pre-conceptions and self-determination are constantly negotiated, and in which we as researchers might also be involved.

An understanding of the interplay between structural (pre-)determination and individual selfdetermination is necessary as is a conceptualisation of agency which abolishes the dichotomy of structural constraints and individual autonomy (Emirbayer and Mische 1998). These approaches continue to assume that assigned legal and juridical positions - such as being a child or being a 'UAM' - are not consistently negotiated in everyday life. In this contribution, however, we argue that individuals are not carriers of fixed characteristics (Emirbayer and Mische 1998), but rather can change their relationships to contexts and thereby influence their life conditions (Geiger 2016, 46). 
Thus, acting in agentic ways merely demonstrates that young people on the move are 'normal' and that it is important to show the ordinariness of their stories and everyday life - or, as Belloni formulated with regard to her own research: "Acknowledging that they can make choices does not make them less vulnerable, it just makes them more human".

Nonetheless, highlighting young people‘s agency throughout their migration process can have implications for public perceptions about their right to be assisted and protected (e.g. Erdal and Oeppen 2017). Although more and more studies progressively engage with the idea that forced and voluntary migration belong to a continuum of situations in which volitional and structural aspects are deeply intertwined, the public debate is still dominated by the binary distinctions between the 'deserving' and the 'bogus' refugee (Holmes and Castaneda 2016). Within this political context, a more real, nuanced and complex description of migrants' choices can constitute a risky ethical enterprise. Does stating that our informants have capabilities, choices and aspirations even in the most constrained and extreme circumstances make them less vulnerable and thus less eligible to legal and social protection? Are we as researchers endorsing anti-refugee claims by saying that our informants could choose to some extent when to leave and where to go? Are we making them responsible for the suffering they have faced along the way if we say that they were aware of the dangers they would face?

While we need to be mindful of our role in these representations, we are not suggesting that they should detract from the importance of truthfully portraying research participants as creative, aware, strong, resilient human beings. But there are other factors which we also need to be aware of. For example, through accentuating what young people can do and the different strategies they adopt to survive or carve out viable futures for themselves within highly constrained circumstances, do we risk bringing these strategies (which sometimes may be bordering on or have crossed the line into illegal activities) to the notice of authorities - and hence put young people at risk of further 
securitisation or marginalisation? Equally, in highlighting how young people advocate for themselves, do we risk undermining efforts to ensure that young people's vulnerabilities are recognised and due response is accorded by statutory services? There are no immediate answers to these questions, but they underline the importance of continuously engaging with ideas of agency and vulnerability in our research with migrant young people and of critically evaluating how, through our work, we may risk over accentuating or undermining either one of these constructs in ways which are detrimental to migrant young people.

\section{Arts and Innovation in Research with Migrant Young People}

There has been an increasing focus on the use of arts in the field of migration, not only as a means to represent the life experiences of migrant communities but also in the processes of generating and constructing new knowledge and multiple examples, which were also employed by different authors of this special issue. Lems (this issue) deployed storytelling not necessarily as a means of generating accurate biographical data but with a focus on the social processes involved in the telling of stories. Because of its intersubjective nature, storytelling has the ability to illuminate at once the teller's hopes, imaginations and ambitions, and the reality of being part of a wider world that often contradicts and shatters these hopes (Jackson 2002). Hence, engaging young people in a process of constructing stories, it was believed, would allow researchers to explore how young people actively made sense of their situations and, if given certain poetic license, how they would choose to reconstruct their experiences.

Yet, despite the innovation in this approach to storytelling, Lems soon realised that the need to tell a 'functional' story was deeply entrenched in how young people initially responded, a phenomenon captured in previous research with unaccompanied refugee youth (e.g. Chase 2010; Ní Raghallaigh 
2013). While the project had been built on the idea that young people could use the radio stories as a tool for reflecting on the reality of being classified as an unaccompanied minor in Switzerland this was not necessarily the story the participants wanted to tell. Lems recognised how initially the young people frequently fell back on rehearsed 'asylum tales', streamlined to fit within the narratives Swiss immigration authorities wanted to hear from them. Given the increasing sense of suspicion the young people are confronted with in the Swiss asylum landscape where they constantly have to over-perform their deservingness as child refugees, the ability to tell a good and acceptable story of themselves took priority over expressing their intimate stories. Lems then changed tack and sought to uncover the sorts of stories that young people did want to tell through the radio shows. Given the choice, they opted to speak through the narratives of pop stars and other heroes, people who they saw as having overcome seemingly insurmountable hurdles. Moreover, left to their own devices, young people by-passed the exhausting amount of time and effort required to create a 'good' radio story in a language that was still new to them and instead opted for short music-driven pieces that did not require them to talk much. While at first glance these radio stories did not seem to offer much insight into the young people's experiences of migration and settlement, their evident need to create a picture of themselves as 'normal', 'ordinary' teenagers, did indeed fling open a window for understanding their struggles to forge connections with Swiss society. Lems discovered that it was only over time and through establishing strong connections that it became possible to place the narratives that young people chose to tell in the storytelling project in the context of their individual situations and biographies.

Lems also came to observe a difference between stories that were designed for a public audience and those that were aimed at more intimate, private settings. Through the medium of radio, the young people told stories with the audience of their Swiss counterparts in mind. Rather than talking about themselves, they mimicked very specific portrayals of Western teenage normality which they hoped their Swiss audience would recognise. Their stories of displacement, on the other hand, were 
not fit to be shared within the public realm of the radio. However, over time the radio project gradually transformed into a hangout space in which private stories of displacement could begin to appear. Lems' insights suggest that it is crucial for researchers working with collaborative storytelling methodologies not to expect the intended outcomes of such projects - the stories - to mirror lived experiences. Rather, scholars need to look deeper and try to uncover the stories behind stories and understand how young people may use the story telling process to communicate in unexpected ways.

Wernesjö (this issue) similarly chose to integrate the arts in her research through combining traditional qualitative interviews with photography-based conversations (Liebenberg 2009; Meloni et al. 2017) and go-alongs (Kusenbach 2003). The aim was to combine these methods to gain a deeper knowledge of young people's everyday lives and experiences through creating possibilities for individuals in marginalised positions to direct the research conversation (Svensson et al. 2009; Holgersson 2011; Svensson 2017), and to build trust with participants through continued engagement over time (Herz and Lalander 2018). However, Wernesjö found that only a third of young people in her study were willing to participate in the go-alongs and photo-based conversations. Young people who resisted considered the methods to be too time-consuming, taking away time from schoolwork and recreational activities. On reflection, Wernesjö believes that young people's reluctance to engage in these more 'innovative' research activities partly stems from inadequate attention to how best to introduce the methods to young people. While preparatory meetings had stressed the importance of gaining knowledge through young people's own voices about their experiences of arriving and beginning to settle in Sweden without their parents or family, the meetings had, however, failed to explain the value of the more exploratory, creative research methods (Wernesjö 2014, 63). 
Chase and colleagues similarly used a broad range of arts-based methods in their research with unaccompanied young people turning 18 (Chase this issue; Meloni this issue; Strasser and Tibet this issue). Over time and through intensive engagement with young people, this work combined photography, poetry, theatre, comedy, music and animation. A number of key reflections stand out from this work. Firstly, that when used in an open, non-prescriptive way, these innovative approaches can certainly give voice to migrant young people in ways which can be stifled by more orthodox interview techniques. Reflections from one of the photography projects (Meloni et al. 2017) speak to how introducing photography helped address some of the 'discomfort' recognised in the research process. Equally, providing resources and space for young people to combine poetry and song enabled young people participating in the project to articulate their own messages. The song 'Becoming adult in another man's world... why are you separating us by borders?' captured ideas developed through a poetry workshop, produced and performed by a band of refugee young musicians in Rome who were not able to secure visas to join the other participants for a workshop in the UK. Yet, while these endeavours may give voice in the short-term, and create enjoyable and fun spaces for co-creation, as artefacts they may bring limited direct benefit to their creators. Honesty and transparency, therefore, about the limitations of what can be achieved through these research innovations are paramount.

Perhaps the core value of these methods is that they constitute a shift away from extractive methods of data collection, in which young people remain largely passive in the formulation of knowledge (Falzone 2004; Gaventa 2005), towards approaches which encourage co-construction and meaningmaking of their experiences. That said, it is crucial as we engage with these methods that we explore beyond their use as tools and recognise the powerful undercurrents in how they define and change the nature of research in sometimes unexpected ways, adding both richness and complexity to what we are taking on as social scientists. One further takeaway point is that these approaches clearly shape the depth of the relationships that are built throughout the research process and 
inevitably force us to ask questions about what happens once the research ends and where that leaves the often deep ties and connections that have been formed. Our experiences suggest that it is important to engage critically with innovative methods and consider how they might be used as alternatives to or in combination with more orthodox research tools. Ultimately, however, wherever possible, the choice of methods, should be a dialogical, open process carried out in consultation with research participants.

\section{Positionality in the Research Process}

A final set of reflections for this paper relate to our own positionality as researchers and how we make decisions about how we conduct ourselves in the research context. The projects reported on in this special issue were conducted, with the exception of one of the researchers, by women with secure European citizenship status, working predominantly with young males conversely in situations of insecurity and uncertainty. There were hence inherent power inequalities to all the projects and gender was an important factor throughout. A number of the researchers were too young to be the young people's mothers, but were, like Otto, often understood as a 'sister', or as 'guests' in front of whom the young people wanted to present themselves as good hosts, e.g. by always cleaning the facility prior to them coming to visit, buying extra food, or as in Wernesjö's case, by showing us around their environments, acting like city guides. In some situations female researchers were understood as persons who needed to be protected by their research participants. For example, Otto was not allowed to accompany the young male refugees to certain places in Malta because they believed that 'it is too dangerous for a girl like you'. These examples show how gender dynamics can simultaneously create closeness and trust between research researchers and participants while also leading to moments of exclusion. 
A common finding in our research was that, despite all being women, we found it harder to engage girls and young women in the respective research projects. This is partly reflective of the fact that across Europe more than 80 percent of the unaccompanied minors seeking asylum are male However, other factors also came into play. Wernesjö (this issue) interprets this result as an outcome of statutory and non-statutory social care institutions being more protective towards young women than young men. More broadly this positioning was indicative of other racialised gender stereotypes the young people were confronted with in their daily lives. These included the widely circulated ascriptions generated in media and public discourse about the supposed uncontrolled sexual danger emanating from African, Muslim and male asylum seekers (Otto and Kaufmann 2018, Allsopp 2017), or the supposed oppression, weakness and abuse of female asylum seekers. Lems (this issue) found that although young women formed an important part of the radio project, they were still very much in a minority. Understanding the gender dynamics at play within the care facility in which she was working was an important part of the research process. This included an awareness of the 'staging' of masculinities (Butler 1988; Mangan 2003) that her own presence or the presence of young women participating in the radio project provoked. It also required attentiveness to gender specific conventions in terms of themes and emotions that could or could not be shared openly or talked about with a female researcher (Allsopp 2018). As the majority of the social workers entrusted with the supervision of the unaccompanied minors were also female, differentiating her role from professionals who may be at the same time associated with care and/ or control was crucially important and something which took time. Interestingly, Lems found that gradually young people started to use the safety of the radio project space to negotiate and discuss gender roles, stereotypes and ascriptions. They initiated heated debates about premarital relationships, love, women in the workforce, violence against women, and the different ways boys or girls experienced their migration to Europe. Rather than passively succumbing to the ascriptions they were confronted with in their own communities as well as in Swiss popular discourse, the young people actively confronted, challenged, debated and parodied these ideas. 
Wernesjö considered how, when she began her research in 2009 , the category of unaccompanied asylum seeking minors was recurring in debates on immigration and reception systems for asylumseekers in Sweden. However, they were rarely given the chance to give their own account of their situations and experiences. Since then, the body of research focusing on the children's own experiences has grown, and in the public debate unaccompanied young people have claimed space to make their voices heard These new directions in research have been inspired by feminist and postcolonial scholars who have argued for the need to really listen to those who are in marginalised positions and to promote social change (Spivak 1988; Mohanty 1984) and they represent a fundamental shift in the positionality of the researcher and what it means to generate knowledge.

A further issue discussed as researchers was that, irrespective of the legal statuses of the young people in our respective research projects, we all need to be cognisant of our non-neutral stance in the research process and the fine line between research and activism. Wernesjö talks about the importance of reciprocal benefits (Mackenzie et al. 2007), or at least giving guidance on where participants who express certain needs or claims can turn. In her experience, this included providing them with contact information about helplines for children, Migration Agency's websites, and organisations and networks which might offer support. It also included providing opportunities to talk about the regulations for family reunification and application processes for citizenship. These acts, and the adoption of research processes designed to enable young people voice their experiences shift the terrain in the research process and blur the line between research and advocacy. Ultimately, many of us in the research described in this special issue could be said to do what Humphries $(2004,113)$ describes as ‘taking sides' (see also Armbuster and Lærke 2008). This requires us as social scientists to declare our partiality openly and position ourselves within a moral and political frame - something which we rarely speak about but which fundamentally determines how we go about our research. 
The positionalities of the researcher and the participants are also shaped by contextual power dynamics. These transcend the migratory experience and include differences outlined earlier such as socio-economic circumstances, education, age (Christensen 2008), ethnicity and race (Back 1996; Lundström 2007; Wernesjö 2014). All contributors shared a sense of discomfort in repeatedly facing these inequalities especially when discussing the experience and impact of issues such as loneliness, exclusion, discrimination and racism. And although we all might strive to redress some of these imbalances through how we engage with young people in the research context, to quote Back $(1996,24)$ it is 'foolish to think that our relationships were completely free from the effects of racism'. A further discomfort emerges from the enormous expectations we place on young people to give and to share - what do/should we give in return. As we carefully delve into the most intimate and private corners of young people's lives, do we, should we in any way, reciprocate with our own thoughts, feelings or experiences? When we shift from quantitative, and arguably objective methods of data extraction towards research encounters which are more flexible and based on ideas of reciprocity, we are surely creating a form of social contract. Yet where we position ourselves, where we draw the lines around reciprocity are factors which we rarely discuss or dare to consider. In this way, however, we cannot completely prevent pressure, which we assert on our research partners. Moreover, a Mauss'ian exchange relationship (1990) is not necessarily characterized by 'friendliness' and 'generosity' alone; instead, 'reciprocity' in an exchange relationship may also include aggressive counter gifts, as demonstrated by Oester and Brunner (2015).

While, in many ways, the researcher is the one who has most power and control in the research situation, research participants can also exercise power in complex ways through forms of resistance or remaining silent, becoming angry or questioning our position as researchers. Wernesjö (this issue) recounted a situation with a 16-year old boy from Afghanistan, who 20 minutes into their first research encounter asked: 'Do you have many questions left?' When she 
replied that it would be okay to have a shorter conversation if he liked, and asked if he was going anywhere. He replied 'No, it's not that. I'm a bit bored [...].' Wernesjö suggests that this is illustrative of participants taking back some control of the conversation and, looking back on transcripts of the conversations, she could recognise several instances where young people sought to regain control over the conversation and resisted the expectation to tell their life stories, instead turning the questions back on the researcher (Wernesjö 2014).

Changes in how we go about research with potentially marginalised constituents of people are fundamentally shaping our roles as researchers and ultimately our position within the research context. We cannot pretend to apply an objective lens to these encounters, we are core protagonists within the processes of constructing knowledge and need to more clearly articulate and reflect our positions when we give an account of the research that we do. Referring back to Humphries notion of 'taking sides' (2004; see also Armbruster and Laerke 2008) we owe it to others not to hide our own moral, political and ethical standpoints but rather to be open on where we stand and reflective of how this inevitably shapes the process of generating new ideas and knowledge.

\section{Conclusion}

In this paper we have shared just some of the "behind-the-scenes-dynamics" of our respective research projects with the aim of jointly constructing new knowledge about doing research with unaccompanied refugee and migrant youth. Through this contribution we hope that we have offered thoughts and insights for stimulating further discussion within this growing research field.

Qualitative research is not a unified experience; every researcher and every research project is different. However, exchange about individual experiences helps to support each other in research. We call for accounts that not only consider migrant young people's voices and experiences, but 
carefully contextualise these within the discourse about them and within the legal and social frameworks they encounter.

We have thought about how an open and combined methodological toolkit was helpful for us in our respective research projects, but we are also mindful of the need to critically apply methodological innovation and constantly consider its potential shortfalls as well as benefits. While we have all adhered to standard ethical codes in our work, we find as researchers that existing ethical guidelines are overly formalistic and do not provide adequate space for the sorts of issues revealed through our joint reflections and experiences of research presented here. We advocate that research ethics should cease being viewed solely as an institutionalised, tick box process within academia which provides the necessary permissions for research. Instead, ethics needs to become more integral to the life of the whole research endeavour, forcing us all to constantly think about the consequences of how we conduct ourselves in the pursuit of knowledge.

Our collective take home message is that while there is no perfect solution in handling the power imbalances in research with migrant young people, we do believe that sharing information and experiences is crucial to fostering more ethical, more reflexive and less harmful social science. The most important ideas we would emphasise from our own work which might help orient future research with young refugees are: First, the importance of not over essentialising young people's experiences of migration but rather being open to the ordinariness of their stories as young people navigating multiple aspects of their lives; Second, as researchers, being constantly mindful of how we are involved in processes of social construction of the 'migrant child'. As such we can buy into the tropes and stereotypes outlined in the introduction to this volume (Lems, Oester and Strasser, this issue), or we can seek to problematise and unsettle them, in so doing, encouraging others to do the same. This links to a third point which is the crucial need to find ways of meaningfully engaging young refugees as research partners in the co-production of knowledge, rather than treating them as 
research objects, thus enabling complex 'stories' to be told and more meaningful representations of young refugees' lives to enter media, public and policy discourse. A final note is to promote careful reflection on how we best access and work with research participants. Should this be through formal institutional structures, informal social networks or, in some cases, a combination of both? Above all we need to recognise that different approaches present advantages and disadvantages for everyone involved and will certainly impact the content, outcomes and relationships born from the research in very different ways.

\section{References}

Allsopp, Jennifer. 2017. 'Agent, victim, soldier, son: Intersecting masculinities in the European “refugee crisis".' In: A Gendered Approach to the Syrian Refugee Crisis, edited by Jane Freedman, Zeynep Kivilcim and Nurcan Özgür Baklacıoğlu, 165-184. London: Routledge.

Althusser, Louis. 1972. 'Ideology and Ideological State Apparatuses' In Lenin and Philosophy and Other Essays, edited by Louis Althusser. Michigan: Monthly Review Press.

Armbruster, Heidi and Anna Lærke. 2008. Taking Sides, Ethics, Politics, and Fieldwork in Anthropology. New York: Berghahn.

Back, Les. 1996. New ethnicities and urban culture: racisms and multiculture in young lives. London: UCL Press.

Belloni, Milena. 2016a. 'Refugees as Gamblers. Eritreans Seeking to Migrate through Italy.' 
Journal of Immigrant \& Refugee Studies 14 (1): 104-119.

Belloni, Milena. 2016b. "“My uncle cannot say no if I reach Libya": unpacking the social dynamics of border-crossing among Eritreans heading to Europe.' Human Geography 9 (2): 47-56.

Belloni, Milena. This issue. 'Family Project or Individual Choice? Exploring the Roots of Young Eritreans' Migration.' Journal of Ethnic and Migration Studies.

Butler, Judith. 2009. Performativity, Precarity and Sexual Politics, available online at www.aibr.org/antropologia/04v03/criticos/040301b.pdf.

Butler, Judith. 1988. Performative Acts and Gender Constitution: An Essay in Phenomenology and Feminist theory. Theatre Journal 40 (4): 519-531.

Carling, Jorgen. 2002. 'Migration in the age of involuntary immobility: theoretical reflections and Cape Verdean experiences.' Journal of Ethnic and Migration Studies 28 (1): 5-42.

Chase, Elaine. 2010. 'Agency and Silence: Young People Seeking Asylum Alone in the UK.' British Journal of Social Work 40 (7): 2050-2068.

Chase, Elaine. 2019. The serendipity of justice: The case of unaccompanied migrant young people becoming 'adult' in the UK. In Peter Aggleton, Alex Broom and Jeremy Moss (Eds) Practical Justice - Principles, Practice and Social Change. London: Routledge 
Chase, Elaine and Jennifer Allsopp. 2019, forthcoming. The Politics of Wellbeing in Transition.

Bristol: Policy Press.

Chase, Elaine. This issue. 'Transitions, Capabilities and Wellbeing: How Afghan Unaccompanied Young People Experience Becoming “Adult” in the UK and Beyond.' Journal of Ethnic and Migration Studies.

Christensen, Pia. 2008. Research with children: Perspectives and practices. London: Falmer Press.

Daniel, Valentine and John C. Knudsen .1995. Mistrusting refugees. Berkeley: University of California Press.

Darling, Jonathan. 2009. 'Becoming bare life: asylum, hospitality, and the politics of encampment.' Environment and Planning D: Society and Space 27 (4): 649-665.

Emirbayer, Mustafa and Ann Mische. 1998. 'What is Agency?' The American Journal of Sociology 103 (4): 962-1023.

Erdal, Marta Bivand and Ceri Oeppen. 2017. 'Forced to leave? The discursive and analytical significance of describing migration as forced and voluntary.' doi.org/10.1080/1369183X.2017.1384149

Falzone, Paul. 2004. 'Transcendent ethnography.' Action Research 2 (3): 326-344

Fernqvist, Stina. 2013. En erfarenhet rikare? En kvalitativ studie av barns strategier och barnfattigdomens villkor. PhD Diss., Uppsala University. 
Fineman, Martha. 2008. 'The Vulnerable Subject: Anchoring Equality in the Human Condition.' Yale Journal of Law \& Feminism 20 (1): 8-40.

Franks, Myfanwy. 2011. 'Pockets of Participation: Revisiting Child-Centred Participation Research.' Children \& Society 25 (1): 15-25.

Gaventa, John. (2005) Claiming Citizenship: Rights, Participation and Accountability London: Zed Books.

Goel, Urmila. 2015. 'From methodology to contextualisation. The politics and epistemology of intersectionality.' Presses de Sciences 2 (58): 25-38.

Geiger, Dorothee 2016. Handlungsfähigkeit von geduldeten Flüchtlingen: Eine empirische Studie auf der Grundlage des Agency-Konzeptes. Wiesbaden: Springer VS.

Goździak, Elzbieta M. 2008. 'On Challenges, Dilemmas, and Opportunities in Studying Trafficked Children.' Anthropological Quarterly 81 (4): 903-924.

Haile Semhar, Habib Rezaie and Francesca Meloni. 2019, forthcoming. 'Negotiating Research and Life Spaces: Participatory Experiences in Research with Unaccompanied Minors in the UK.' In Refuge in a Moving World, edited by Elena Fiddian-Qasmiyeh. London: UCL Press.

Herz, Marcus and Philip Lalander. 2018. 'An abstract and nameless, but powerful, bystander "unaccompanied children" talking about their social workers in Sweden.' Nordic Social Work Research, doi: 10.1080/2156857X.2018.1457558 
Hoffmann, Felix. 2017. Zur kommerziellen Normalisierung illegaler Migration. Akteure in der Agrarindustrie von Almería, Spanien. Bielefeld. Transcript.

Holgersson, Helena. 2011. Icke-medborgarskapets urbana geografi. Göteborg: Glänta.

Holmes, Seth M. and Heide Castañeda. 2016. 'Representing the "European refugee crisis" in Germany and beyond: Deservingness and difference, life and death.' American Ethnologist 43(1): $12-24$.

Hopkins, Peter. 2008. 'Ethical issues in research with unaccompanied asylum-seeking children.' Children's Geographies 6 (2): 257-268.

Humphries, Beth. 2004. 'Taking Sides: Social Work Research As a Moral and Political Activity.' The Journal of Sociology and Social Welfare 32 (1): 113-129.

Jackson, Michael. 2002. The Politics of Storytelling: Violence, Transgression, and Intersubjectivity. Copenhagen: Museum Tusculanum Press.

James, Allison. 2007. ‘Giving Voice to Children's Voices: Practices and Problems, Pitfalls and Potentials.' American Anthropologist 109 (2): 261-272.

Kusenbach, Margarethe. 2003. 'Street phenomenology: The go-along as ethnographic research tool.' Ethnography 4 (3): 455-485.

Lems, Annika. 2018. Being-Here: Placemaking in a World of Movement. London and New York: Berghahn. 
Lems, Annika. This issue. 'Being Inside Out: The Slippery Slope between Inclusion and Exclusion in a Swiss Educational Project for Unaccompanied Refugee Youth.’ Journal for Ethnic and Migration Studies.

Lems, Annika, Kathrin Oester and Sabine Strasser. This issue. 'Children of the Crisis: Ethnographic Perspectives on Unaccompanied Refugee Youth in and En Route to Europe.' Journal of Ethnic and Migration Studies.

Liebenberg, Linda. 2009. 'The visual images as discussion point: increased validity in boundary crossing research.' Qualitative Research 9 (4): 441-467.

Lubkemann, Stephen C. 2008. 'Involuntary immobility: on a theoretical invisibility in forced migration studies.' Journal of Refugee Studies 21 (4), 454-475.

Lundström, Catrin. 2007. Svenska Latinas: Ras, klass och kön i svenskhetens geografi. Göteborg: Makadam.

Mackenzie, Catriona, Christopher McDowell C and Eileen Pittaway. 2007. 'Beyond "Do No Harm": The Challenge of Constructing Ethical Relationships in Refugee Research.' Journal of Refugee Studies 20 (2): 299-319.

Malkki, Liisa. 1994. 'Citizens of Humanity: Internationalism and the Imagined Communities of Nations.' Diaspora: A Journal of Transnational Studies 3 (1): 41-68. 
Malkki, Liisa. 1995. 'Refugees and Exile: From „Refugee Studies“ and the national Order of Things.' Annual Review of Anthropology 24: 495-523.

Mangan, Michael. 2003. Staging Masculinities: History, Gender, Performance. London: Palgrave Macmillan.

Mauss, Marcel. 1990 (1922). The Gift: forms and functions of exchange in archaic societies. London: Routledge.

Meloni, Francesa, Elaine Chase and Semhar Haile. 2017. Walking a Tightrope: Unaccompanied migrant young people, transitions and futures. London: UCL.

Meloni, Francesca. This issue. 'The Limits of Freedom: The Uncertainty of Choice without Moral Guidance among Afghan Migrant Youth.' Journal of Ethnic and Migration Studies.

Mohanty, Chandra Talpade. 1984. 'Under Western eyes: Feminist scholarship and colonial discourses.' Boundary 2 (12): 333,358.

Ní Raghallaigh, Muireann. 2013. 'The Causes of Mistrust amongst Asylum Seekers and Refugees: Insights from Research with Unaccompanied Asylum-Seeking Minors Living in the Republic of Ireland.' Journal of Refugee Studies 27 (1): 82-100. 
Oester, Kathrin and Bernadette Brunner. 2015. 'Jean Rouch Back in School: Teaching and research as a parallel process through media projects with adolescents in Switzerland.' Visual Ethnography 4 (1): $5-23$

Otto, Laura and Margrit E. Kaufmann. 2018: “"Minderjährig“, "männlich" - "stark"?

Bedeutungsaushandlungen der Selbst- und Fremdzuschreibung junger Geflüchteter in Malta. Eine intersektionelle Leseweise ethnografischer Forschungsausschnitte. Gender 2: 63-78.

Otto, Laura. This issue. 'Children, Adults, or both? Negotiating Adult Minors and Interests in a State Care Facility in Malta.' Journal of Ethnic and Migration Studies.

Punch, Samantha. 2002. 'Research with Children: The Same or Different from Research with Adults?' Childhood 9 (3): 321-341.

Reichertz, Jo. 2015. 'Die Bedeutung der Subjektivität der Forschung.' Forum Qualitative Sozialforschung 16(3). Online: http://www.qualitativeresearch.net/index.php/fqs/article/viewFile/2461/3889.

Rousseau, Cécile. 1993. 'The place of the unexpressed: Ethics and methodology for research with refugee children.' Canada's Mental Health 41 (4): 12-16.

Spivak, Gayatri Chakravorty. 1988. 'Can the subaltern speak?' In Marxism and the interpretation of culture, edited by Cary Nelson and Lawrence Grossberg. 271-313. London: Macmillan.

Spyrou, Spyros. 2017. 'Time to decenter childhood?' Childhood 24 (4): 433-437. 
Strasser, Sabine, and Eda Elif Tibet. This issue. 'The Border Event in the Everyday: Hope and Constraints in the Life of Young Unaccompanied Asylum Seekers in Turkey.' Journal of Ethnic and Migration Studies.

Svensson, Malin. 2017. Hoppet om en framtidsplats. Asylsökande barn i den svenska skolan. PhD Diss., University of Gothenburg.

Svensson, Malin, Ekblad Solvig, and Henry Ascher. 2009. 'Making meaningful space for oneself: photo-based dialogue with siblings of refugee children with severe withdrawal symptoms.' Children's Geographies 7 (2): 209-228.

Turner, Bryan, S. 1993. Outline of a Theory of Human Rights. Sociology, 27 (3), 489-512.

Vervliet, Marianne, Cécile Rousseau, Eric Broekaert, and Ilse. 2015. 'Multilayered ethics in research involving unaccompanied refugee minors.' Journal of Refugee Studies 28 (4): 468-485.

Wahlström Smith, Åsa, and Henry Ascher. 2016. 'Forskning med flyktingbarn i en papperslös situation - på eller tillsammans med? Etiska utmaningar och erfarenheter.' In Irreguljär migration $i$ Sverige. Rättigheter, vardagserfarenheter, motstånd och statliga kategoriseringar, edited by Maja Sager, Klara Öberg and Helena Holgersson. Göteborg: Daidalos.

Wernesjö, Ulrika. 2012. 'Unaccompanied asylum-seeking children: Whose perspective?' Childhood 19 (4): 495-507. 
Wernesjö, Ulrika 2014. Conditional belonging: Listening to unaccompanied young refugees' voices. PhD Diss., Uppsala University.

Wernesjö, Ulrika. This issue. 'Across the Threshold: Negotiations of Deservingness among Unaccompanied Young Refuges in Sweden.' Journal of Ethnic and Migration Studies. 